\title{
Editorial: Os estudos líticos em países lusófonos
}

\author{
João Carlos Moreno de Sousa ${ }^{1}$, Astolfo Gomes de Mello Araujo ${ }^{2}$ \\ 1. Museu Nacional, Universidade Federal do Rio de Janeiro. Quinta da Boa Vista, s/n, Rio de Janeiro, Brasil. \\ Email: jcmorenodesousa@gmail.com \\ 2. Instituto de Estudos Avançados, Museu de Arqueologia e Etnologia, Universidade de São Paulo, Brasil. \\ Email: astwolfo@usp.br
}

Organizar uma coletânea de artigos sobre estudos líticos em língua portuguesa não parece, a princípio, uma tarefa desafiadora. Afinal, Portugal já tem uma tradição de décadas de pesquisas no tema, as quais também têm aumentado no Brasil nos últimos anos. Logo, era de se esperar que a maioria dos artigos publicados nesta edição fossem provenientes destes dois países. O desafio está em incluir artigos sobre pesquisas realizadas em outros países lusófonos, pois estes possuem poucas ou nenhuma instituição de pesquisas arqueológicas. E dos estudos realizados sobre as indústrias líticas nestes países, a maioria é realizada por pesquisadores vindos da América do Norte ou da Europa, em especial os próprios arqueólogos portugueses.

Após várias chamadas para publicação nesta edição, e convites realizados diretamente a arqueólogos de departamentos de pesquisa arqueológica em países lusófonos conseguimos apenas um artigo que não trata das indústrias portuguesas ou brasileiras, sendo este o artigo de Nicoll com os resultados de uma pesquisa sobre artefatos encontrados ao longo do rio Cunene, na fronteira entre Angola e Namíbia.

Esta edição ainda reúne quatro artigos sobre indústrias líticas brasileiras e quatro sobre indústrias portuguesas. Os artigos brasileiros tratam majoritariamente de indústrias líticas do Sudeste e Sul do Brasil. Correa e Souza abordam dois abrigos rochosos com ocupações humanas datadas do Holoceno Médio e Final no Centro-Sul do Estado de São Paulo; Okumura e Araujo realizam uma análise morfométrica das pontas bifaciais encontradas por todo Sudeste e Sul do Brasil; Lourdeau e colegas apresentam o primeiro registro de núcleos laminares em território brasileiro; Penha apresenta um levantamento geológico das jazidas de matéria-prima lítica no Brasil. Os artigos portugueses focam, principalmente, em indústrias localizadas na Estremadura e no Ribatejo. Cunha e colegas tratam da ocupação humana mais antiga na Ibéria Ocidental, datada do Paleolítico Inferior; Gameiro apresenta um estudo sobre a percussão branda (macia) na debitagem lamelar durante o Magdalenense; Goufa e colegas tratam das estratégias de produção e circulação de lâminas e lamínulas durante o Paleolítico Médio; Jordão apresenta dados a respeito da funcionalidade e proveniência das pontas líticas da região de Zambujal.

Portugal e Brasil definitivamente possuem uma maior quantidade de estudos líticos sendo realizados em relação aos outros países onde a língua portuguesa é o idioma oficial, mas ainda assim nota-se uma maior concentração de pesquisas correntes nas regiões do ISSN: 2055-0472. URL: http://journals.ed.ac.uk/lithicstudies/

This work is licensed under a Creative Commons Attribution 2.5 UK: Scotland License. 
Centro-Oeste de Portugal e do Sudeste e Sul do Brasil. Esperamos que este número especial do "Journal of Lithic Studies" possa se configurar como uma iniciativa pioneira, que dê margem a um maior intercâmbio entre acadêmicos trabalhando com materiais líticos em países lusófonos e estimule a publicação de números ulteriores, com a contribuição de colegas trabalhando em outros países da África e Ásia, bem como em outras regiões de Portugal e Brasil. É sempre importante lembrar que informações publicadas nas línguas de origem são, às vezes, a melhor maneira de divulgação efetiva entre alunos e mesmo colegas cuja segunda língua não é o inglês.

J. C. Moreno de Sousa

A. G. M. Araujo

Editores convidados 


\title{
Editorial: Lithic studies in Portuguese-speaking countries
}

\author{
João Carlos Moreno de Sousa ${ }^{1}$, Astolfo Gomes de Mello Araujo ${ }^{2}$ \\ 1. Museu Nacional, Universidade Federal do Rio de Janeiro. Quinta da Boa Vista, s/n, Rio de Janeiro, Brazil. \\ Email: jcmorenodesousa@gmail.com \\ 2. Instituto de Estudos Avançados, Museu de Arqueologia e Etnologia, Universidade de São Paulo, Brazil. \\ Email: astwolfo@usp.br
}

Organizing a collection of articles on lithic studies in Portuguese does not seem, at first, a challenging task. After all, Portugal already has a tradition of decades of research on the subject, which has also increased in Brazil in recent years. Therefore, it was expected that most of the articles published in this edition would come from these two countries. The challenge was to include articles on research carried out in other Portuguese-speaking countries, as they have few or no archaeological research institutions. And of the studies on the lithic industries in these countries, most are carried out by researchers from North America or Europe, especially Portuguese archaeologists.

After several calls for papers for this issue, and invitations made directly to archaeologists of archaeological research departments in Portuguese-speaking countries, we have only one article that does not deal with Portuguese or Brazilian industries, this being Nicoll's article with the results of a research on artefacts found along the Cunene River, on the border between Angola and Namibia.

This issue also brings together four articles on Brazilian lithic industries and four articles on Portuguese industries. Brazilian articles deal mainly with lithic industries in southeastern and southern Brazil. Correa and Souza present two rockshelters with human occupations dating from the Middle and Late Holocene in the centre-south of the state of São Paulo; Okumura and Araujo perform a morphometric analysis of the bifacial points found throughout southeast and southern Brazil; Lourdeau and colleagues present the first record of laminar cores within the territory of Brazil; Penha presents a geological survey of lithic raw material deposits in Brazil. The Portuguese articles focus mainly on industries located in Estremadura and Ribatejo. Cunha and colleagues deal with the oldest human occupation in western Iberia, dating from the Lower Palaeolithic; Gameiro presents a study about soft percussion in lamellar debitage during the Magdalenian; Goufa and colleagues discuss the strategies of production and circulation of blades and bladelets during the Middle Palaeolithic period; Jordão presents data on the functionality and provenance of lithic points in the Zambujal region of Portugal.

Portugal and Brazil definitely have a larger amount of lithic studies being carried out in relation to the other countries where Portuguese is the official language, but there is still a greater concentration of current research in the regions of the centre-west of Portugal and the southeast and south of Brazil. We hope that this special issue of the "Journal of Lithic Studies” will act as a pioneering initiative that will lead to a greater exchange among academics working with lithic materials in Portuguese-speaking countries, stimulating the publication of later issues, with the contribution of colleagues working in other countries in Africa and Asia, as well as in other regions of Portugal and Brazil. It is always important to 
remember that information published in the mother languages is sometimes the most effective way to communicate between students and colleagues whose second language is not English.

J. C. Moreno de Sousa

A. G. M. Araujo

Gueest Editors 